\title{
The modE gene product mediates molybdenum-dependent expression of genes for the high-affinity molybdate transporter and modG in Azotobacter vinelandii
}

\author{
Nigel J. Mouncey, ${ }^{1} \dagger$ Lesley A. Mitchenall ${ }^{1,2}$ and Richard N. Pau ${ }^{1,2}$ \\ Author for correspondence: Richard N. Pau. Tel: +44 1603 456900. Fax: +44 1603454970. \\ e-mail:pau@bbsrc.ac.uk
}

1 Nitrogen Fixation Laboratory, University of Sussex, Brighton BN1 9RQ, UK

2 John Innes Centre, Nitrogen Fixation Laboratory, Norwich Research Park, Colney, Norwich NR4 7UH, UK

\begin{abstract}
The Azotobacter vinelandii mod locus, which is involved in high-affinity molybdate transport and the early events in Mo metabolism, consists of two divergently transcribed operons, $\bmod G$ and $\bmod E A B C$. $\bmod A, \bmod B$ and $\bmod C$ encode the components of the high-affinity molybdate transporter, and modG encodes a Mo-binding protein. High concentrations of Mo repressed transcription of both operons. The modEABC operon was also repressed by tungstate and to a lesser extent by vanadate. modE, the first gene in the modEABC operon, controlled the Mo-dependent transcription of both operons. It was not involved in the metal regulation of alternative nitrogenase gene expression. Although a modE mutant constitutively expressed genes encoding the molybdate transporter, it had a reduced rate of Mo accumulation.
\end{abstract}

Keywords: molybdenum, molybdate, regulation and transport, vanadium, nitrogenase

\section{INTRODUCTION}

Mo is required for the synthesis of the molybdopterinbased cofactors (Mo-co) of about 20 redox enzymes, and the $\mathrm{Fe}_{7} \mathrm{~S}_{9} \mathrm{Mo}$ cofactor (FeMoco) of Mo nitrogenase (Dean et al., 1993; Kim \& Rees, 1992; Stiefel, 1993). Mo is present at low concentrations and neutral $\mathrm{pH}$ in the environment as the oxyanion molybdate, $\mathrm{MoO}_{4}^{2-}$. Bacteria employ a high-affinity ATP-binding cassette (ABC) transporter to efficiently scavenge traces of molybdate from the environment (Fleishmann et al., 1995; Maupin-Furlow et al., 1995; Mouncey et al., 1995; Rech et al., 1995; Wang et al., 1993). In Arotobacter vinelandii, a distinct low-affinity transporter has been shown to be responsible for molybdate acquisition when the concentration of molybdate is high $(>10 \mu \mathrm{M})$ (Mouncey et al., 1995; Premakumar et al., 1996). Escherichia coli grown in low sulfate concentrations also transports molybdate by the sulfate transporter, though it does so much less efficiently than with the high-affinity molybdate transporter (Rosentel et al., 1995).

There are only a few well-documented cases of transcriptional regulation by Mo among the genes known to be

† Present address: Department of Microbiology and Molecular Genetics, Harvard Medical School, 200 Longwood Avenue, Boston MA 02115, USA. involved in Mo transport and metabolism. The first concerns genes for molybdate transport. The high-affinity molybdate transporter is encoded by three genes, $\bmod A$, $\bmod B$ and $\bmod C$, which are located in a single operon. Transcription of $E$. coli $\bmod A$ and $\bmod C$, which respectively encode the periplasmic molybdate-binding protein and the inner-membrane ATP-binding protein of the transporter, is repressed by high concentrations of molybdate (Miller et al., 1987; Rech et al., 1995; Surin et al., 1985). Low-affinity molybdate transport in $A$. vinelandii is repressed in a mutant strain that expresses the high-affinity system constitutively, and it consequently accumulates Mo by this system, even when the concentration of Mo is high (Mouncey et al., 1995). Secondly, Mo transcriptionally regulates the reciprocal expression of the Mo and alternative nitrogenases in $A$. vinelandii (Jacobitz \& Bishop, 1992; Jacobson et al., 1986; Luque \& Pau, 1991; Walmsley et al., 1994). In addition to these cases, Mo has also been implicated in the regulation of $E$. coli nar $G$ and frd $A$ expression through the involvement of the narX gene product (Stewart, 1993). A putative regulatory motif has been identified in the promoter of the $E$. coli $\bmod A B C D$ operon and the regulatory system responsible for the control of Mo transport is currently being elucidated (Maupin-Furlow et al., 1995; Rech et al., 1995). modR (also called modE) has recently been shown to be involved in the transcriptional regulation of the $E$. coli mod ABCD operon (Walkenhorst et al., 1995). 
The products of two genes in the A. vinelandii mod locus, $\bmod E$ and $\bmod G$, contain a tandem repeat of a sequence homologous to the molybdopterin-binding proteins, Mop, of Clostridium pasteurianum (Mouncey et al., 1995). Whereas the Mop-like tandem repeat constitutes the whole of ModG, it is restricted to the C-terminal half of ModE. modE is the first gene in the $\bmod E A B C$ operon which is transcribed divergently from $\bmod G$. Mutational analysis of $\bmod E$ and $\bmod G$ indicated that their gene products are not involved in molybdate transport, but they may have a role in the homeostasis and early metabolism of Mo (Mouncey et al., 1995). Genes homologous to $A$. vinelandii modE are present in $E$. coli (accession nos U07867 and U27192), Haemophilus influenzae (amino acid position numbers 491878-4919447, TIGR database; Fleishmann et al., 1995) and Rbodobacter capsulatus (Wang et al., 1993). In E. coli and H. infuenzae, a single modE-like gene is transcribed divergently from the $\bmod A B C D$ operon, while in $R$. capsulatus there are two copies of $\bmod E$-like genes that are called $\operatorname{mop} A$ and $\operatorname{mop} B$. $\operatorname{mop} A$ is cotranscribed with $\bmod A B C D$, like $\bmod E$ in $A$. vinelandii. $m \circ p B$ is divergently transcribed from the $R$. capsulatus mop $A \bmod A B C D$ operon. The alternative nitrogenase of $R$. capsulatus is not repressed by $M o$ in a double $m o p A \operatorname{mop} B$ mutant as it is in the wild-type strain. This suggests that both $m o p A$ and $\operatorname{mop} B$ are involved in Modependent regulation of the alternative nitrogenase (Wang et al., 1993). In this paper, we describe the metaldependent regulation of $A$. vinelandii $\bmod E A B C$ and $\bmod G$ operons, and show that the regulation of both is mediated by the product of modE. However, the Modependent expression of alternative nitrogenase structural genes was independent of the modE control, and the Mo accumulation of a modE mutant was not that predicted if the product of $\bmod E$ was solely involved in the transcriptional regulation of Mo transport.

\section{METHODS}

Bacterial strains and growth conditions. E. coli strains were grown at $37^{\circ} \mathrm{C}$ in Luria Bertani (LB) medium (Miller, 1972) and A. vinelandii was grown at $30^{\circ} \mathrm{C}$ in modified Burks medium (Pau et al., 1989). The latter was made Mo-free by treatment with 8hydroxyquinoline followed by continuous liquid-liquid extraction with 1,2-dichloroethane as described previously (Mouncey et al., 1995). Analytical grade chemicals, and plastic or glassware soaked for $>16 \mathrm{~h}$ in a surface-active cleaning agent $(2.5 \%, \mathrm{v} / \mathrm{v}$, Decon 90 ; Decon Laboratories), were used to reduce contamination by transition metals. Highly purified sodium molybdate, vanadium pentoxide and sodium tungstate were added to the media as required (Puratronic grade, $<10$ p.p.m. of total metal impurities; Johnson Mathey Chemicals). Sodium nitrate $(10 \mathrm{mM})$ or ammonium acetate $(20 \mathrm{mM})$ were added as necessary. Antibiotics were added at the following final concentrations: carbenicillin, $200 \mu \mathrm{g} \mathrm{m} \mathrm{m}^{-1}(E$. coli); kanamycin $(\mathrm{Km}), 2 \mu \mathrm{g} \mathrm{ml}^{-1}$ (A. vinelandii) and $25 \mu \mathrm{g} \mathrm{ml}^{-1}$ (E. coli); spectinomycin, $2 \mu \mathrm{g} \mathrm{ml}^{-1}$ (A. vinelandii) and $25 \mu \mathrm{g} \mathrm{ml}^{-1}$ (E. coli). Strains used are shown in Table 1.

DNA manipulations and transformation. Standard procedures were used, as described in Sambrook et al. (1987). Chromosomal mutants in mod genes were constructed by the introduction of either the promoterless lac $Z-\mathrm{Km}$-resistance cassette from pKOK6.1 or the spectinomycin-resistance cassette $(\Omega)$ from
pHP45 into mod genes cloned in a plasmid vector, followed by the recombination of the mutated gene into the chromosome of the wild-type strain UW136 (Mouncey et al., 1995). pKOK6.1 has stop codons in all three reading frames upstream of the lac $Z$ gene. A. vinelandii cells were made competent by growth on solid medium lacking $\mathrm{Mo}$ and $\mathrm{V}$, and transformed by the method of Page \& von Tigerstrom (1979). The inf $\mathrm{H}-l a c Z$ $\bmod E-\Omega$ and anfH-lac $Z$ modE- $\Omega$ double mutants were constructed by transforming the vnfH-lac Z and anfH-lacZ mutants MV107 and MV143 (Walmsley et al., 1994) with plasmid pLAM86441, which contains $\operatorname{modE}-\Omega$ (Mouncey et al., 1995). $\bmod A-\mathrm{KOK}$ anfH-lac $Z, \bmod B-\mathrm{KOK}$ anfH-lac $Z$ and $\bmod C-\mathrm{KOK}$ anf $\mathrm{H}-\mathrm{lac} Z$ double mutants were constructed by transforming strain MV143 with the plasmids pNM144, pNM206 and pNM238, which respectively contain $\bmod A, \bmod B$ and $\bmod C$, with the cassette from pKOK6.1 inserted in the orientation where the lac $Z$ gene is not transcribed (Mouncey et al., 1995).

In-frame $\mathrm{N}$-terminal modE deletion mutation. Two DNA fragments with complementary $18 \mathrm{bp} 5^{\prime}$ overhangs on either side of the sequence encoding the $\mathrm{N}$-terminal domain of ModE were first synthesized by PCR using Vent polymerase (New England Biolabs). For each reaction, $2.5 \mathrm{pmol}$ primers and $100 \mathrm{ng}$ template were used. The DNA was denatured for $1 \mathrm{~min}$ at $95^{\circ} \mathrm{C}$, the primers were annealed at $54{ }^{\circ} \mathrm{C}$ for $1 \mathrm{~min}$, and the products were extended over $2 \mathrm{~min}$ at $72^{\circ} \mathrm{C}$. The $644 \mathrm{bp}$ fragment containing DNA that encodes the promoter region and start codon of modE was obtained using primers 94018 (5' TGAGCGGATAACAATTTCACACAGGAAACAGCTATGACCATG-3') and 94110 (5'-GTTGCGCGCGCTGGTCTTCATCGTCTGGTAGCCTGC-3') and pNM631 as a template. pNM631 contains modE and the sequence up to the $B c l$ site in the $5^{\prime}$ end of $\bmod A$. The $1636 \mathrm{bp}$ fragment with a sequence that encodes the C-terminal end of modE was obtained using primers 94108 (5' -AAGACCAGCGCGCGCAACCAGTTCGCCGGCATCG-3') and 94017 (5'-GT'TTTCCCAGTCACGACGTTGTAAAACGACGGCCAG-3') and pMac75 as a template. The $18 \mathrm{bp} 5^{\prime}$ overhangs are underlined above. The plasmids used are described by Mouncey et al. (1995). The two PCR products were purified using Wizard PCR purification columns (Promega), annealed, and a single cycle of a PCR reaction was performed in the absence of primers. Primers 94018 and 94017 were then added and the PCR reaction was allowed to proceed for a further 19 cycles to give a $2162 \mathrm{bp}$ product which contained the inframe $\mathrm{N}$-terminal deletion. The reaction was performed as above, except that the annealing temperature was $40^{\circ} \mathrm{C}$. The product was digested with $P_{s t} \mathrm{I}$ and cloned into Pst $\mathrm{I}$-digested pTZ18 to give plasmid pNM796. The sequence and in-frame deletion of the cloned DNA was confirmed using the chaintermination DNA sequencing method with $\left[{ }^{35} \mathrm{~S}\right] \mathrm{dATP} \alpha \mathrm{S}, 7-$ deaza-dGTP and a modified T7 polymerase (Sequenase, series 2; Amersham). DNA from plasmid pNM796 was then separately mixed with the DNA from plasmid pNM239, which contains the $\mathrm{KOK}$ cassette inserted into $\bmod C$ in the $\mathrm{Lac}^{+}$ orientation. The DNA mixture was then used to transform $A$. vinelandii strain RP20, which possesses a $\bmod E: \Omega$ insertion mutation. Transformants were selected on the basis of their $\mathrm{Km}$ resistance and checked for the spectinomycin-sensitive phenotype. The $\operatorname{modE}:: \Omega$ mutation in the parent strain was replaced by the region of plasmid pNM796 which contains the modE Nterminal deletion and its flanking DNA, and the KOK cassette was inserted into $\bmod C$. The resulting strain, RP55, lacks the sequence encoding the $\mathrm{N}$-terminal domain of modE.

Enzyme assay. $\beta$-Galactosidase activity of whole cells permeabilized with chloroform and SDS was determined by the hydrolysis of ONPG at $30^{\circ} \mathrm{C}$ as previously described by Miller 
Table 1. Bacterial strains used

\begin{tabular}{|c|c|c|}
\hline Bacterial strain & Genotype & Reference \\
\hline \multicolumn{3}{|c|}{ Azotobacter vinelandii } \\
\hline UW136 & rift & Bishop \& Brill (1977) \\
\hline MV107 & vnfH7:: $\operatorname{Tn} 5-\mathrm{B} 21$ & Walmsley et al. (1994) \\
\hline MV143 & rif1 anfH1:: $\operatorname{Tn} 5-\mathrm{B} 21$ & Walmsley et al. (1994) \\
\hline RP2 & $\operatorname{modE}::^{\prime} l a c Z-\mathrm{Km}\left(\mathrm{Lac}^{+}\right), \phi\left(\operatorname{modE}-^{\prime} l a c Z-\mathrm{Km}\right)(\mathrm{Hyb})$ from $\mathrm{pNM} 149$ & Mouncey et al. (1995) \\
\hline $\mathrm{RP} 4$ & $\bmod A:^{\prime} \mathrm{lac} \mathrm{Z}-\mathrm{Km}\left(\mathrm{Lac}^{+}\right), \phi\left(\bmod A-{ }^{\prime} l a c Z-\mathrm{Km}\right)(\mathrm{Hyb})$ from $\mathrm{pNM} 145$ & Mouncey et al. (1995) \\
\hline RP6 & $\operatorname{modB}::^{\prime} l a c Z-\mathrm{Km}\left(\mathrm{Lac}^{+}\right), \phi\left(\operatorname{modB}-^{\prime} l a c Z-\mathrm{Km}\right)(\mathrm{Hyb})$ from pNM207 & Mouncey et al. (1995) \\
\hline RP8 & $\bmod C::^{\prime} l a c Z-\mathrm{Km}\left(\mathrm{Lac}^{+}\right), \phi\left(\bmod C-{ }^{\prime} l a c Z-\mathrm{Km}\right)(\mathrm{Hyb})$ from $\mathrm{pNM} 239$ & Mouncey et al. (1995) \\
\hline RP10 & $\begin{array}{l}\bmod A::^{\prime} l a c Z-\mathrm{Km}\left(\mathrm{Lac}^{+}\right), \phi\left(\bmod A-{ }^{\prime} l a c Z-\mathrm{Km}\right)(\mathrm{Hyb}) \text { from } \mathrm{pNM} 145 \\
\bmod E:: \Omega \text { from } \mathrm{pLAM} 86441\end{array}$ & This work \\
\hline RP12 & $\bmod G::^{\prime} l a c Z-\mathrm{Km}\left(\mathrm{Lac}^{+}\right), \phi\left(\bmod G-^{\prime} l a c Z-\mathrm{Km}\right)(\mathrm{Hyb})$ from $\mathrm{pLAM} 86682$ & Mouncey et al. (1995) \\
\hline RP14 & $\begin{array}{l}\bmod G::^{\prime} l a c Z-\mathrm{Km}\left(\mathrm{Lac}^{+}\right), \phi(\bmod G-' l a c Z-\mathrm{Km})(\mathrm{Hyb}) \text { from } \mathrm{pLAM} 86682 \\
\bmod :: \Omega \text { from } \mathrm{pLAM} 86441\end{array}$ & Mouncey et al. (1995) \\
\hline RP20 & $\bmod E:: \Omega$ from $\mathrm{pLAM} 86441$ & Mouncey et al. (1995) \\
\hline RP21 & vnfH7::Tn5-B21, modE:: $\Omega$ from pLAM86441 & This work \\
\hline RP23 & anfH1::Tn5-B21, $\bmod E:: \Omega$ from $\mathrm{pLAM} 86441$ & This work \\
\hline RP36 & $\begin{array}{l}\text { anfH1:: Tn } 5-\mathrm{B} 21, \bmod A::^{\prime} l a c Z-\mathrm{Km}\left(\mathrm{Lac}^{-}\right), \phi\left(\bmod A--^{\prime} l a c Z-\mathrm{Km}\right) \\
(\mathrm{Hyb}) \text { from pNM144 }\end{array}$ & This work \\
\hline $\mathrm{RP} 37$ & $\begin{array}{l}\text { anfH1::Tn5-B21, modB::'lacZ-Km }\left(\mathrm{Lac}^{-}\right), \phi\left(\bmod B-^{\prime} l a c Z-\mathrm{Km}\right) \\
\text { (Hyb) from pNM206 }\end{array}$ & This work \\
\hline RP38 & $\begin{array}{l}\text { anfH1:: Tn5-B21, } \bmod C::^{\prime} l a c Z-\mathrm{Km}\left(\mathrm{Lac}^{-}\right), \phi\left(\bmod C-{ }^{\prime} \mathrm{lac} Z-\mathrm{Km}\right) \\
(\mathrm{Hyb}) \text { from pNM238 }\end{array}$ & This work \\
\hline RP55 & $\begin{array}{l}\bmod E \mathrm{~N} \text {-terminal deletion from } \mathrm{pNM} 796, \bmod C::^{\prime} l a c Z-\mathrm{Km}\left(\mathrm{Lac}^{+}\right) \\
\phi\left(\bmod C-^{\prime} l a c Z-\mathrm{Km}\right)(\mathrm{Hyb}) \text { from pNM239 }\end{array}$ & This work \\
\hline RP61 & $\begin{array}{l}\bmod G:: \mathrm{Km}^{-} l a c Z\left(\mathrm{Lac}^{-}\right), \phi\left(\bmod G-\mathrm{Km}^{-} \mathrm{lac} Z\right)(\mathrm{Hyb}) \text { from pLAM86681, } \\
\bmod \mathrm{L}: \Omega \text { from pLAM86441, vnfH7::Tn5-B21 }\end{array}$ & This work \\
\hline RP62 & $\begin{array}{l}\bmod G::^{\prime} l a c Z-\mathrm{Km}\left(\mathrm{Lac}^{-}\right), \phi\left(\bmod G-{ }^{\prime} l a c Z-\mathrm{Km}\right)(\mathrm{Hyb}) \text { from } \mathrm{pLAM} 86681 \\
\bmod :: \Omega \text { from } \mathrm{pLAM} 86441, \text { anf } \mathrm{H} 1:: \operatorname{Tn} 5-\mathrm{B} 21\end{array}$ & This work \\
\hline \multicolumn{3}{|l|}{ Escherichia coli } \\
\hline $71-18$ & $\Delta($ lac-pro $A B)$ thi supE $\left(\mathrm{F}^{\prime}\right.$ pro $A B$ lac $\left.I^{\mathrm{q}} \mathrm{Z} \Delta \mathrm{M} 15\right)$ & Yanisch-Perron et al. (1985) \\
\hline
\end{tabular}

(1972). Each assay was performed in triplicate and the results are the means of assays from three separate cultures. The maximum standard deviation was $12 \%$ of any mean value.

Western blot analysis. After overnight growth in medium containing different concentrations of Mo, A. vinelandii cells were harvested by centrifugation and resuspended to give equal cell densities $\left(\mathrm{OD}_{600}=1\right)$. A $100 \mu$ quantity of the resuspended cells was mixed with $100 \mu \mathrm{I} 2 \times$ SDS sample buffer, boiled, and then centrifuged to remove cell debris. Samples $(10 \mu \mathrm{l})$ of the extracted proteins were separated by SDS-PAGE on $12.5 \%$ $(\mathrm{w} / \mathrm{v})$ polyacrylamide gels and transferred to polyvinylidene difluoride membranes (Immobilon-P; Millipore) by semi-dry electrotransfer in $10 \mathrm{mM}$ CAPS and $10 \%(\mathrm{v} / \mathrm{v})$ methanol. The periplasmic molybdate-binding protein (ModA) was detected immunochemically with the enhanced chemiluminescence Western blotting system (ECL; Amersham) using polyclonal rabbit antiserum against purified $A$. vinelandii molybdatebinding protein $(1: 2000$ dilution) and a goat anti-rabbit horseradish-peroxidase-labelled second antibody $(1: 10000 \mathrm{di}-$ lution) (Mouncey et al., 1995). The density of the luminescence signals was quantified from the digitized film image using the NIH Image 1.55 program. There was a linear relationship between density and protein concentration from 0 to $125 \mathrm{ng}$ purified molybdate-binding protein.

${ }^{99} \mathrm{Mo}$ accumulation. ${ }^{99} \mathrm{Mo}$ was recovered from spent ${ }^{99} \mathrm{Mo} /{ }^{99 \mathrm{~m}} \mathrm{Tc}$ radionuclide generators by elution with disodium hydrogen phosphate (Baldock et al., 1994). ${ }^{99}$ Mo was added to $2.5 \mathrm{ml}$ cells $\left(\mathrm{OD}_{600}=1\right)$ in modified Burks medium at $30^{\circ} \mathrm{C}$. At timed intervals, $500 \mu \mathrm{l}$ aliquots of cells were removed, filtered with $2.5 \mathrm{~mm}$ diameter, $0.45 \mu \mathrm{m}$ pore-size, HAWP-type membrane filters (Millipore) on a multiple filter vacuum manifold, and washed with $10 \mathrm{ml} 150 \mathrm{mM} \mathrm{NaCl}$ and $30 \mathrm{mM}$ potassium phosphate, $\mathrm{pH} 7 \cdot 2$. The filters were dried and radioactivity was measured in a liquid scintillation counter. The rates of ${ }^{99} \mathrm{Mo}$ accumulation were linear over $20 \mathrm{~min}$.

\section{RESULTS}

\section{The modEABC and modG operons are regulated by Mo, $W$ and $V$}

Strains with chromosomal lac $Z$ fusions in $\bmod A, \bmod B$ and $\bmod C$ showed maximal $\beta$-galactosidase activity when they were grown in medium that contained less than $10 \mathrm{nM} \mathrm{Mo}$, and the activity was progressively reduced as the concentration of Mo increased above this (Fig. 1). The Mo concentration required for the half-maximal activity was $100 \mathrm{nM}$, the same as that required for the halfmaximal activity of an $E$. coli $\bmod C-l a c Z$ fusion strain (Miller et al., 1987). When the $\operatorname{modB}$ fusion strain was grown in $>1 \mu \mathrm{MMO}$, it showed less than $5 \%$ of the maximal $\beta$-galactosidase activity (Fig. 1). At between 1 


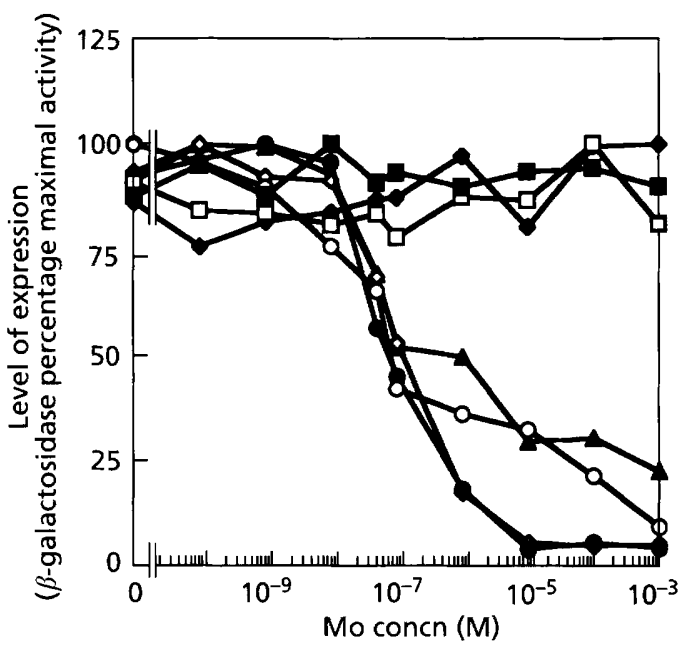

Fig. 1. $\beta$-Galactosidase activities of the $A$. vinelandii modE-lac $Z$ mutant RP2 (口), modA-lacZ mutant RP4 (O), modB-lacZ mutant RP6 (O), modC-lacZ mutant RP8 ( $\diamond)$, modG-lacZ mutant RP12 ( $\Delta)$, modA-lacZ modE- $\Omega$ double mutant RP10 ( $\square$ ) and modG-lacZ modE- $\Omega$ double mutant RP14 ( $\bullet)$. The strains were grown overnight in different concentrations of Mo and in the presence of $10 \mathrm{mM} \mathrm{NaNO}_{3}$. One hundred per cent activity corresponds to 122 Miller units for modE-lacZ, 125 Miller units for modA-lacZ, 315 Miller units for modB-lacZ, 271 Miller units for modC-lacZ and 60 Miller units for modG-lacZ.

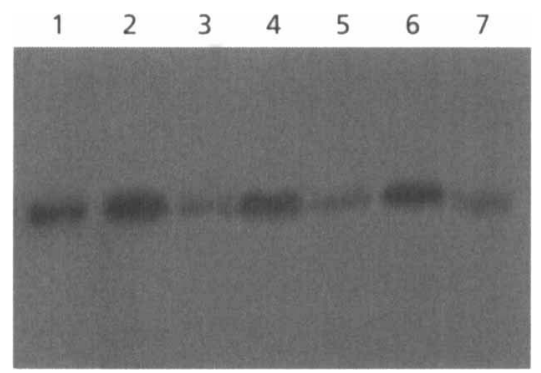

Fig. 2. Western blot analysis of the periplasmic molybdatebinding protein ModA from the wild-type $A$. vinelandii strain UW136 grown in different concentrations of Mo and different nitrogen sources. Lanes: 1, $31 \mathrm{ng}$ purified periplasmic molybdate-binding protein ModA; 2 and 3, strain UW136 grown in the absence of a source of fixed nitrogen in either the absence of Mo or the presence of $1 \mathrm{mM} \mathrm{Mo}$, respectively; 4 and 5 , strain UW136 grown in the presence of $1 \mathrm{mM}$ nitrate in either the absence of Mo or the presence of $1 \mathrm{mMMo}$, respectively; 6 and 7, strain UW136 grown in the presence of $20 \mathrm{mM} \mathrm{NH}_{4}^{+}$in either the absence of Mo or the presence of $1 \mathrm{mM} \mathrm{Mo}$, respectively.

and $100 \mu \mathrm{M} \mathrm{Mo}$, somewhat higher activities were found in the $\bmod A-l a c Z$ fusion strain, which decreased to approximately $12 \%$ of the maximal activity at $1 \mathrm{mM}$ Mo.

Mo-dependent repression of the Mo transporter was also observed at the level of protein synthesis in the wild-type strain by immunochemical detection of ModA, the periplasmic molybdate-binding protein. The amount of ModA in cells grown in $1 \mathrm{mM}$ Mo was $4-8 \%$ of that found in cells grown in the absence of Mo (Fig. 2). This

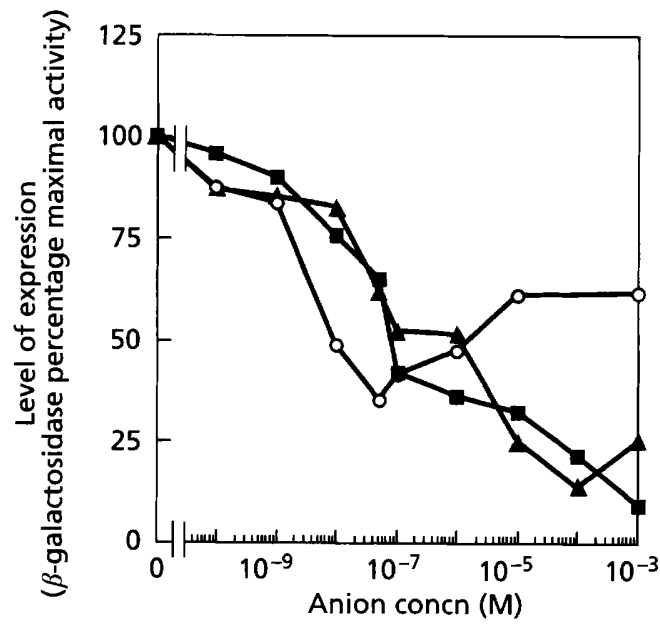

Fig. 3. $\beta$-Galactosidase activity of a $\bmod A-l a c Z$ fusion strain RP4 grown in increasing concentrations of Mo $(\square), V(O)$ and $W$ (A). Cells were grown overnight at $30^{\circ} \mathrm{C}$ in the presence of $\mathrm{NH}_{4}^{+}$. One hundred per cent activity corresponds to 98 Miller units in Mo, 100.2 Miller units in V and 94.6 Miller units in W.

was similar to the repression of $\beta$-galactosidase activity observed in $\bmod A-$ and $\bmod B-l a c Z$ fusion strains.

The $\beta$-galactosidase activity of a $\bmod G$-lac $Z$ fusion strain was also regulated by Mo (Fig. 1) in a similar response to increasing Mo concentration as the $\bmod A B C-$ lac $Z$ fusion strains, suggesting that the transcription of both operons may be subject to the same Mo-dependent control mechanism.

In $A$. vinelandii, W can replace Mo to produce an inactive nitrogenase, or one with reduced activity which contains both Mo- and W-containing cofactors (Benemann et al., 1973; Hales \& Case, 1987). V is incorporated into the cofactor of the $A$. vinelandii $\mathrm{V}$ nitrogenase, where it occupies the position equivalent to that occupied by Mo in the Mo nitrogenase cofactor (Eady, 1995). Because Mo, $\mathrm{W}$ and $\mathrm{V}$ can be incorporated into the cofactors of $A$. vinelandii nitrogenases, it was of interest to determine whether high-affinity Mo transport was regulated by $W$ and $\mathrm{V}$ as well as Mo. The $\beta$-galactosidase activity of a $\bmod A-l a c Z$ fusion strain showed that $\mathrm{W}$ was as effective as Mo in repressing $\bmod A-$-lac $Z$ transcription (Fig. 3 ). When the $\bmod A$-lac $Z$ fusion strain was grown in the presence of $\mathrm{V}, \beta$-galactosidase activity decreased to about $50 \%$ of its maximum value as the concentration of $\mathrm{V}$ increased to $100 \mu \mathrm{M}$, which suggests that the Mo sensor may also be able to sense $\mathrm{V}$ as effectively as Mo and $\mathrm{W}$ up to this concentration. The response of $\beta$-galactosidase activity to $\mathrm{V}$ concentration above $100 \mu \mathrm{M}$ differed from that observed with Mo and W, for it increased or remained constant.

\section{modE is involved in Mo regulation of the modEABC operon and the modG gene}

In contrast to the $\bmod A-, \bmod B-$ and $\bmod C-l a c Z$ fusion strains described above, a $\operatorname{modE}-\operatorname{lac} Z$ insertion/deletion fusion strain showed no significant change in $\beta$ - 


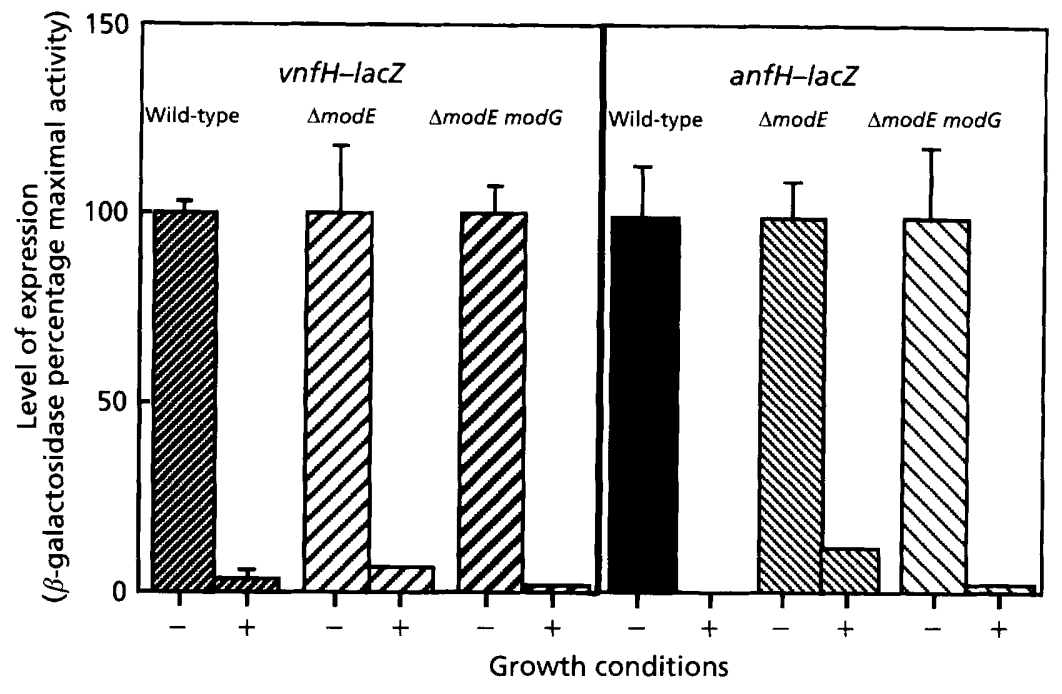

Fig. 4. $\beta$-Galactosidase activities of $\mathrm{VnfH}$ and anfH-lac $Z$ fusion strains in the absence and presence of Mo. Cells were derepressed for nitrogenase for $6 \mathrm{~h}$ at $30^{\circ} \mathrm{C}$ in either the absence $(-)$ or the presence $(+)$ of $100 \mathrm{nM}$ Mo. Strains: MV107, vnfH-lacZ (四) RP21, vnfH-lacZ modE- $\Omega$ (Z); RP61, vnfH-lacZ modE- $\Omega$ modG-KOK ( $(\mathbb{Z}) ; \mathrm{MV} 143$ anfH-lacZ ( $\mathbf{(})$; RP23, anfH-lacZ $\operatorname{modE}-\Omega$ $(\mathbb{N}) ; \mathrm{RP62}$, anfH-lacZ modE- $\Omega$ modG-KOK (\$). One hundred per cent activity corresponds to 4607 Miller units for $v n f H-l a c Z$ and 5013 Miller units for anfH-lacZ. galactosidase activity with increasing Mo concentration (Fig. 1). Transcription of a $\bmod A-l a c Z$ fusion was also constitutive in a strain (strain RP10) with a non-polar insertion/deletion mutation in modE (Fig. 1). Further, a non-polar $\bmod E$ insertion/deletion mutation relieved the repression of $\bmod G-l a c Z$ transcription by $M o$ in strain RP14 (Fig. 1). A mutant (strain RP55) was constructed which contained a modC-lac $Z$ fusion as well as an in-frame deletion in $\operatorname{modE}$, which removes the sequence encoding the N-terminal domain of ModE. Like the $\operatorname{modE}$ insertion/deletion mutants, the $\beta$-galactosidase activities of this double mutant were constitutive with respect to increasing Mo concentration (data not shown). These results indicate that the modE gene product mediates the Mo-dependent repression of both of the divergently transcribed operons in the $A$. vinelandii mod locus.

\section{ModE is not involved in the regulation of alternative nitrogenases by Mo}

In $R$. capsulatus, the two ModE-like gene products MopA and $\mathrm{MopB}$ regulate the Mo repression of the alternative nitrogenase. Since $A$. vinelandii ModE mediated the Modependent repression of both $\bmod E A B C$ and $\bmod G$, it was of interest to see whether it also regulated the repression of the alternative nitrogenases. vnfH and anfH encode the Fe proteins of the $\mathrm{V}$ nitrogenase and nitrogenase-3, respectively (Joerger et al., 1989, 1990). Repression is observed with Mo concentrations above $50 \mathrm{nM}$ (Jacobson et al., 1986). Comparison of the $\beta$-galactosidase activities of vnfH-lacZ and anfH-lacZ fusion strains (MV107 and MV143) with the activities of strains which also contained a mutation in modE (strains RP21 and RP23) showed that ModE did not mediate the Mo-dependent repression of vnfH-lac $\mathrm{Z}$ and anfH-lac $\mathrm{Z}$ (Fig. 4). Repression of $v n f H$ and anfH by Mo was also observed in strains (RP61 and RP62) with mutations in both $\bmod E$ and $\bmod G$ (Fig. 4). Further, Mo-dependent repression of $v n f H$ and anf $H$ was not affected by deletions in $\bmod A, \bmod B$ or $\bmod C$ (strains RP36, RP37 and RP38) (data not shown).

\section{The rates of Mo accumulation in a modE mutant}

Since ModE mediates the Mo-dependent repression of the molybdate transporter, a non-polar modE mutant would be expected to show maximal rates of Mo transport since the high affinity Mo-transport system is being synthesized constitutively. Further, the nitrate reductase activity of the non-polar modE mutant is similar to the wild-type strain, except above $100 \mu \mathrm{M}$ Mo. The insertion/deletion mutation in modE in strain RP20 is non-polar since this strain synthesizes wild-type levels of the periplasmic molybdate-binding protein, the product of $\bmod A$ (Mouncey et al., 1995). Nevertheless, at ${ }^{\mathbf{9 9}} \mathrm{Mo}$ concentrations $>10 \mathrm{nM}$, the rates of ${ }^{99}$ Mo accumulation in this mutant were significantly lower than in the wild-type strain (Fig. 5a). Since accumulation reflects the rate of influx, efflux, storage and conversion to cofactors, it was also of interest to compare the rate of ${ }^{99}$ Mo accumulation in cells grown in different nitrogen sources. Mo is utilized for the synthesis of the Mo nitrogenase or nitrate reductase cofactors in the absence of a source of fixed nitrogen or in the presence of nitrate, respectively. In the presence of $\mathrm{NH}_{4}^{+}$, neither cofactor is produced. Mo is then transported into the cell and stored. Although ModA synthesis is not repressed by the presence of $\mathrm{NH}_{4}^{+}$(Fig. 2), the initial rate of ${ }^{99} \mathrm{Mo}$ accumulation was much lower in cells grown in $\mathrm{NH}_{4}^{+}$than in the absence of a source of fixed nitrogen or in the presence of nitrate (Fig. 5b).

\section{DISCUSSION}

The results show that modE mediates the Mo-dependent regulation of transcription of the two operons in the mod locus of $A$. vinelandii. Unlike the case in E. coli, where the regulatory gene is encoded in a separate operon, in $A$. vinelandii the regulatory gene is in the same operon as the genes encoding the components of the transporter (Luque et al., 1993; Walkenhorst $e$ t al., 1995). A. vinelandii modE is presumably autoregulated since the intergenic region between $\bmod E$ and $\bmod A$ is short and there is no evidence for the presence of a promoter between $\bmod E$ and $\bmod A$, or within the $3^{\prime}$ end of modE. 

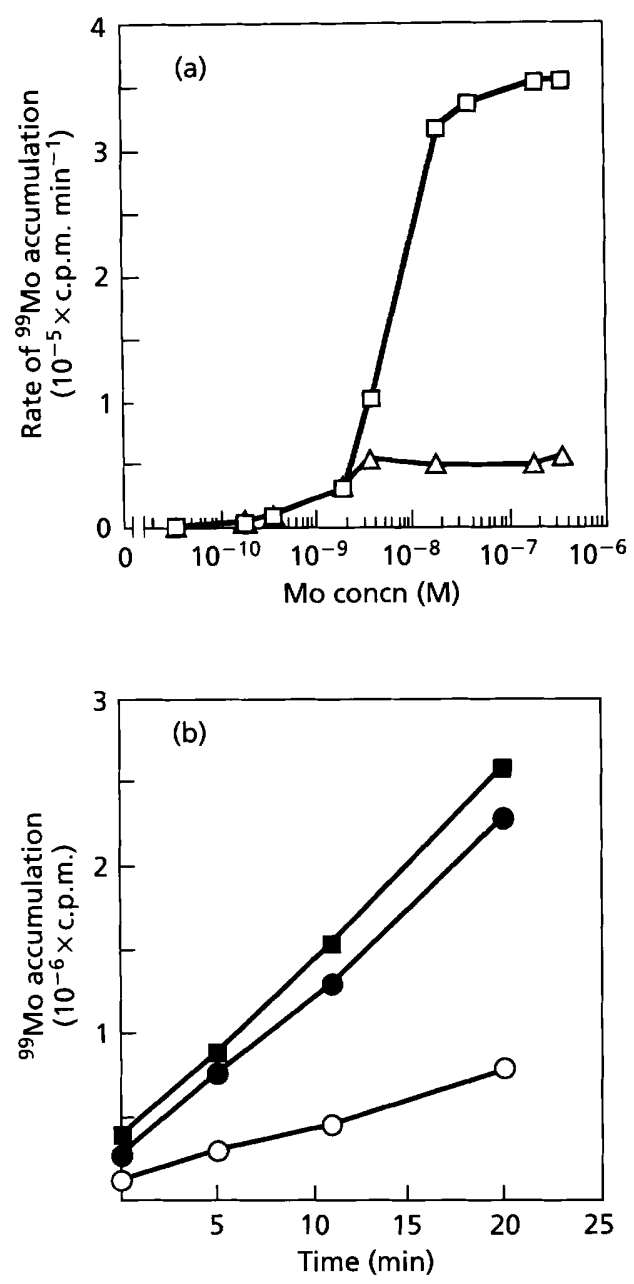

Fig. 5. (a) Rates of ${ }^{99} \mathrm{Mo}$ accumulation in the wild-type $A$. vinelandii strain UW136 ( $\square$ ) and a modE mutant, RP20 ( $\triangle$ ), grown in increasing concentrations of Mo. Cells were grown overnight in the presence of $10 \mathrm{mM} \mathrm{NaNO}_{3}$ and $100 \mathrm{nM}$ Mo and washed with Mo-free media. The rates of ${ }^{99} \mathrm{Mo}$ accumulation were determined from the amounts accumulated at $0,5,11$ and $20 \mathrm{~min}$. (b) ${ }^{99} \mathrm{Mo}$ accumulation of $A$. vinelandii wild-type strain UW136 grown in different media with different nitrogen sources. Cells were grown overnight at $30^{\circ} \mathrm{C}$ in the presence of $20 \mathrm{mM} \mathrm{NH}_{4} \mathrm{Ac}(\mathrm{O})$ or $10 \mathrm{mM} \mathrm{NaNO}_{3}(\boldsymbol{\square})$ or in the absence of a source of fixed nitrogen (0). Cells were washed and ${ }^{99} \mathrm{Mo}$ was added at a final concentration of $1.6 \mu \mathrm{M}$.

Genes encoding proteins involved in the regulation of transport as well as in the early steps of substrate metabolism are also found in genetic loci that encode the transporters of other oxyanions, such as phosphate, sulfate and arsenate. In the Pst phosphate-transport system of E. coli, a regulatory and metabolic role are combined in the product of phoU, which has no role in transport (Hryniewicz et al., 1990; Ji \& Silver, 1992; Laudenbach \& Grossman, 1991; Rosen et al., 1995; Steed \& Wanner, 1993; Wanner, 1993). In the sulfate- and arsenatetransport loci, regulatory proteins and sulfate or arsenate reductases are encoded by separate genes (Hryniewicz et al., 1990; Laudenbach \& Grossman, 1991; Ji \& Silver, 1992; Rosen et al., 1995). ModE is distinctive in that the two halves of the molecule are very different, as shown by sequence homology, in which the C-terminal half is equivalent to ModG, or a fused dimer of $C$. pasteurianum Mop (Mouncey et al., 1995). This difference receives further support from the predicted secondary structure of ModE, which shows that the $\mathrm{N}$-terminal half consists almost entirely of $\alpha$-helices, while the C-terminal half consists of $\beta$-sheets (data not shown). Since a $\bmod G$ mutation does not affect Mo-dependent regulation of the $\bmod E A B C$ operon, the $\bmod G$ protein must have an independent non-regulatory role or have lost its ability to regulate. This suggests that the $\mathrm{N}$-terminal domain of $\operatorname{modE}$ has a regulatory role. It is not known whether the regulatory function requires interaction between the $\mathrm{N}$ and $\mathrm{C}$-terminal domains, or the $\mathrm{N}$-terminal domain alone.

In $E$. coli, expression of a $\bmod A-$-lac $Z$ fusion introduced into the chromosome could only be observed in strains with a mutation in one of the Mo-transporter genes (Rech et al., 1995). This contrasts with the demonstration of ModA synthesis in wild-type $A$. vinelandii cells, though the disparity may be due to the concentration of residual Mo in the $E$. coli culture medium $(<1 \mu \mathrm{M})$, which may have been sufficient to repress transcription of the mod operon to low levels unless Mo transport is impaired. The $E$. coli phosphate transporter is involved in the negative control of phosphate-dependent genes (Cox et al., 1989). The observation that Mo represses $\bmod E A B C$ transcription in $A$. vinelandii strains with an inactivated highaffinity transporter raises the question of whether Mo is sensed intra- or extracellularly, and whether there are components in the regulatory system other than ModE. If the $A$. vinelandii Mo sensor senses intracellular Mo, then it must sense low levels which enter the cell when the highaffinity transporter is inactivated. Our results also show that the repression of the $A$. vinelandii alternative nitrogenase structural gene transcription is independent of modE control, and can take place in cells with a nonfunctional high-affinity Mo transporter. ModE is therefore not a global regulator of $\mathrm{Mo-controlled} \mathrm{genes} \mathrm{in} A$. vinelandii. This was unexpected, since deletion of the two modE-like genes (mop $A$ and $m o p B$ ) in R. capsulatus allowed the alternative nitrogenase to be expressed in the presence of Mo. In E. coli, mutations located outside the mod locus have been shown to affect Mo-dependent regulation (Hemschemeier et al., 1991; Lee et al., 1990). A. vinelandii may likewise possess more than one Mo-dependent regulatory system.

Demonstration of $A$. vinelandii ModA synthesis in the presence of $\mathrm{NH}_{4}^{+}$is in accord with early observations which showed that Mo uptake in $A$. vinelandii was not repressed when the cells were grown in media containing a source of fixed nitrogen, as it was in Klebsiella pneumoniae and C. pasteurianum (Elliott \& Mortenson, 1975; Pienkos \& Brill, 1981). W represses Mo transport in $C$. pasteurianum and Azospirillum brasilense and $\bmod C$ expression in E. coli (Elliott \& Mortenson, 1975; Chauret et al., 1992; Miller et al., 1987). In Azotobacter cbroococcum, a species closely related to $A$. vinelandii, the progressive increase in $\mathrm{V}$ nitrogenase activity with rising $\mathrm{V}$ concentration in the nanomolar range is indicative of high- 
affinity V transport (Robson et al., 1986). However, unlike tungstate and molybdate, vanadate does not compete for radioactive molybdate bound to the periplasmic molybdate-binding protein of $A$. vinelandii, which suggests that the high-affinity molybdate-uptake system is not used to transport $\mathrm{V}$ into the cell (Mouncey et al., 1995). This may reflect the different species of $\mathrm{V}$ and Mo oxyanions in aqueous solution at low concentrations and approximately neutral $\mathrm{pH}$ (Willsky, 1990). Mo is present as $\mathrm{MoO}_{4}^{2-}$ and $\mathrm{V}$ as a mixture of $\mathrm{H}_{2} \mathrm{VO}_{4}^{-}$and $\mathrm{HVO}_{4}^{2-}$, protonated forms of $\mathrm{VO}_{4}^{3-}$ with greater similarity to phosphate than to molybdate. In Neurospora crassa, vanadate uptake occurs via a phosphate-transport system (Bowman, 1983). The derinonstration that transcription of the mod operon is repressed by V up to a concentration of $100 \mathrm{nM}$ suggests that the metal sensor responds to similar species of Mo and V up to this concentration of V. The lack of repression at higher $V$ concentrations may reflect concentration-dependent changes in the species of vanadate which the sensor recognizes. Monomeric species of vanadate decrease with increasing $\mathrm{V}$ concentration (Willsky, 1990).

Measurement of ${ }^{99} \mathrm{Mo}$ accumulation does not distinguish between processes which affect the rate of molybdate transport or subsequent steps in Mo metabolism. The molybdate transporter is fully expressed in non-polar $\bmod E$ mutants, which show wild-type nitrate reductase activity, except at high Mo concentration (Mouncey et al., 1995). It was therefore surprising to find that the rates of ${ }^{99}$ Mo accumulation of cells in the presence of $>10 \mathrm{nM}$ molybdate were significantly reduced in a $\bmod E$ mutant (RP20) compared to the wild-type strain, though they were sufficient for nitrate reductase cofactor biosynthesis. One explanation is that the rate of Mo accumulation reflects the level of intracellular Mo. Such a situation may be seen in wild-type cells grown in the presence of different nitrogen sources. Since the expression of the molybdate transporter was found to be comparable in all cases, the lower rate of accumulation in the presence of $\mathrm{NH}_{4}^{+}$probably reflects the absence of cofactor biosynthesis, and only represents Mo transported into the cells and bound to 'storage' proteins. The absence of lags in the rates indicates that the differential rates do not depend on de novo protein synthesis. The lower initial rate of ${ }^{99} \mathrm{Mo}$ accumulation in the non-polar modE mutant may likewise be due to the absence of an intracellular sink or pool for Mo. The similarity of the C-terminal half of ModE with a tandem repeat of C. pasteurianum Mop, and ModG, suggests that ModE may be a bifunctional protein. In addition to functioning as a negative regulator, it may have a role as an intracellular Mo-binding protein. Alternatively, it is possible that ModE regulates other unknown genes that are involved in Mo transport or accumulation.

\section{ACKNOWLEDGEMENTS}

We are most grateful to C. Baldock, Dr J. E. Lutkin and P. Barnes of the Department of Nuclear Medicine, Royal Sussex County Hospital for providing ${ }^{99} \mathrm{Mo}$. We also thank Professor
W. Lotz for pKOK6.1, S. Austin for the antiserum to $A$. vinelandii peripiasmic molybdate-binding protein, W. Cannon and $M$. Buck for oligonucleotides, S. Hinton for discussions and access to unpublished data, and G. Sawers for reading the manuscript. N. J.M. is in receipt of a BBSRC postgraduate studentship.

\section{NOTE ADDED IN PROOF}

Recently, molybdate-dependent binding of the product of E. coli $\bmod E$ to the promoter of $\bmod A B C D$ has been observed (Grunden et al., 1996, J Bacteriol 178, 735-744).

\section{REFERENCES}

Baldock, C. P., Pau, R. N., Barnes, P. \& Lutkin, J. E. (1994). Production of molybdenum from radionuclide generators for the investigation of genes associated with molybdenum transporters. Nucl Med Commun 15, 264.

Benemann, J. R., Smith, G. M., Kostel, P. J. \& McKenna, C. E. (1973). Tungsten incorporation into Azotobacter vinelandii nitrogenase. FEBS Lett 29, 219-221.

Bishop, P. E. \& Brill, W. J. (1977). Genetic analysis of Azotobacter vinelandii mutant strains unable to fix nitrogen. $J$ Bacteriol 130 , 954-956.

Bowman, B. J. (1983). Vanadate uptake in Neurospora crassa occurs via phosphate transport system II. J Bacteriol 153, 286-291.

Chauret, C., Barraquio, W. L. \& Knowles, R. (1992). Molybdenum incorporation in denitrifying Azospirillum brasilense Sp7. Can J Microbiol 38, 1042-1047.

Cox, G. B., Webb, D. \& Rosenberg, H. (1989). Specific amino acid residues in both the PstB and PstC proteins are required for phosphate transport by the Escherichia coli Pst system. J Bacteriol 171, 1531-1534.

Dean, D. R., Bolin, J. T. \& Zheng, L. (1993). Nitrogenase metalloclusters: structures, organization and synthesis. J Bacteriol 175, 6737-6744.

Eady, R. R. (1995). The enzymology of biological nitrogen fixation. Sci Prog 78, 1-17.

Elliott, B. K. \& Mortenson, L. E. (1975). Transport of molybdate by Clostridium pasteurianum. J Bacteriol 124, 1295-1301.

Fleishmann, R. D., Adams, M. D., White, O., Clayton, R. A., Kirkness, E. F., Kerlavge, A. R., Bult, C. J., Tomb, J. F., Dougherty, B. A., Merrick, J. M., McKenney, K., Sutton, G., Fitzhugh, W., Fields, C., Gocayne, J. D., Scott, J., Shirley, R., Liu, L. I., Glodek, A., Kelley, J. M., Weidman, J. F., Phillips, C. A., Spriggs, T., Hedblom, E., Cotton, M. D., Utternack, T. R., Hanna, M. C., Nguyen, D. T., Saudek, D. M., Brandon, R. C., Fine, L. D., Fritchman, J. L., Fuhrmann, J. L., Geoghagen, N. S. M., Gnehm, C. L., McDonald, L. A., Small, K. V., Fraser, C. M., Smith, H. O. \& Venter, J. C. (1995). Whole-genome random sequencing and assembly of Haemophilus influenzae. Science 269, 496-512.

Hales, B. J. \& Case, E. E. (1987). Nitrogen fixation by Azotobacter vinelandii in tungsten-containing medium. $J$ Biol Chem 262, 16205-16211.

Hemschemeier, S., Grund, M., Keuntje, B. \& Eichenlaub, R. (1991). Isolation of Escherichia coli mutants defective in the uptake of molybdate. J Bacteriol 173, 6499-6506.

Hryniewicz, M., Sirko, A., Palucha, A., Böck, A. \& Hulanicka, D. (1990). Sulfate and thiosulfate transport in Escherichia coli K-12: identification of a gene encoding a novel protein involved in thiosulfate binding. J Bacteriol 172, 3358-3366. 
Jacobitz, S. \& Bishop, P. E. (1992). Regulation of nitrogenase-2 in Azotobacter vinelandii by ammonium, molybdenum, and vanadium. J Bacteriol 174, 3884-3888.

Jacobson, M. R., Premakumar, R. \& Bishop, P. E. (1986). Transcriptional regulation of nitrogen fixation by molybdenum in Azotobacter vinelandii. J Bacteriol 167, 480-486.

Ji, G. \& Silver, S. (1992). Reduction of arsenate to arsenite by the ArsC protein of the arsenic resistance operon of the Staphylococcus aureus plasmid pI258. Proc Natl Acad Sci US A 89, 9474-9478.

Joerger, R. D., Jacobson, M. R., Premakumar, R., Wolfinger, E. D. \& Bishop, P. E. (1989). Nucleotide sequence and mutational analysis of the structural genes (anfHDGK) for the second alternative nitrogenase from Azotobacter vinelandii. J Bacteriol 171, 1075-1086.

Joerger, R. D., Loveless, T. M., Pau, R. N., Mitchenall, L. A., Simon, B. H. \& Bishop, P. J. (1990). Nucleotide sequences and mutational analysis of the structural genes for nitrogenase 2 of Azotobacter vinelandii. J Bacteriol 172, 3400-3408.

Kim, J. \& Rees, D. C. (1992). Crystallographic structure and functional implications of the nitrogenase molybdenum-iron protein from Azotobacter vinelandii. Nature 360, 553-560.

Laudenbach, D. E. \& Grossman, A. R. (1991). Characterisation and mutagenesis of sulphur-regulated genes in a cyanobacterium: evidence for function in sulphate transport. J Bacteriol 173, 2739-2750.

Lee, J. H., Wendt, J. C. \& Shanmugam, K. T. (1990). Identification of a new gene, molR, essential for utilization of molybdate by Escherichia coli. J Bacteriol 172, 2079-2087.

Luque, F. \& Pau, R. N. (1991). Transcriptional regulation by metals of structural genes for Azotobacter vinelandii nitrogenases. Mol Gen Genet 227, 481-487.

Luque, F., Mitchenall, L. A., Chapman, M., Christine, R. \& Pau, R. N. (1993). Characterization of genes involved in molybdenum transport in Azotobacter vinelandii. Mol Microbiol 7, 447-459.

Maupin-Furlow, J. A., Rosentel, J. K., Lee, J. H., Deppenmeier, U., Gunsalus, R. P. \& Shanmugam, K. T. (1995). Genetic analysis of the $\bmod A B C D$ (molybdate transport) operon of Escherichia coli. $J$ Bacteriol 177, 4851-4856.

Miller, J. H. (1972). Experiments in Molecular Genetics. Cold Spring Harbor, NY : Cold Spring Harbor Laboratory.

Miller, J., Scott, D. \& Amy, N. (1987). Molybdenum-sensitive transcriptional regulation of the chlD locus of Eschericbia coli. $J$ Bacteriol 169, 1853-1860.

Mouncey, N. J., Mitchenall, L. A. \& Pau, R. N. (1995). Mutational analysis of genes of the mod locus involved in molybdenum transport, homeostasis and processing in Arotobacter vinelandii. $J$ Bacteriol 177, 5294-5302.

Page, W. J. \& von Tigerstrom, M. (1979). Optimal conditions for the transformation of Azotobacter vinelandii. J Bacteriol 139, 1058-1061.

Pau, R. N., Mitchenall, L. A. \& Robson, R. L. (1989). Genetic evidence for an Azotobacter vinelandii nitrogenase lacking molybdenum and vanadium. $J$ Bacteriol 171, 124-129.

Pienkos, P. T. \& Brill, W. J. (1981). Molybdenum accumulation and storage in Klebsiella pneumoniae and Azotobacter vinelandii. J Bacteriol $145,743-751$
Premakumar, R., Jacobitz, S., Ricke, S. C. \& Bishop, P. E. (1996). Phenotypic characterisation of a tungsten-tolerant mutant of Azotobacter vinelandii. J Bacteriol 178, 691-696.

Rech, S., Deppenmeier, U. \& Gunsalus, R. P. (1995). Regulation of the molybdate transport operon, $\bmod A B C D$, of Escherichia coli in response to molybdate availability. J Bacteriol 177, 1023-1029.

Robson, R. L., Eady, R. R., Richardson, T. H., Miller, R. W., Hawkins, M. \& Postgate, J. R. (1986). The alternative nitrogenase of Azotobacter cbroococcum is a vanadium enzyme. Nature 322, 388-390.

Rosen, B. P., Shi, W. \& Wu, J. (1995). Regulation of the arsenical resistance operon. J Cell Biocbem S1A SIA, 240.

Rosentel, J. K., Healy, F., Maupin-Furlow, J. A., Lee, J. H. \& Shanmugam, K. T. (1995). Molybdate and regulation of mod (molybdate transport), $f d b F$, and byc (formate hydrogenlyase) operons in Escherichia coli. J Bacteriol 177, 4857-4864.

Sambrook, J., Fritsch, E. F. \& Maniatis, T. (1987). Molecular Cloning: a Laboratory Manual, 2nd edn. Cold Spring Harbor, NY: Cold Spring Harbor Laboratory.

Steed, P. M. \& Wanner, B. L. (1993). Use of the reptechnique for allele replacement to construct mutants with deletions of the pstSCAB-phoU operon: evidence of a new role for the PhoU protein in the phosphate regulon. J Bacteriol 175, 6797-6809.

Stewart, V. (1993). Nitrate regulation of anaerobic respiratory gene expression in Escherichia coli. Mol Microbiol 9, 425-434.

Stiefel, E. I. (1993). Molybdenum enzymes, cofactors and chemistry. In Molybdenum Enzymes, Cofactors and Model Systems. ACS Symposium Series 535, pp. 1-18. Edited by E. I. Stiefel, D. Coucouvanis \& W. E. Newton. Washington, DC: American Chemical Society.

Surin, B. P., Rosenberg, H. \& Cox, G. B. (1985). Phosphate-specific transport system of Escherichia coli: nucleotide sequence and genepolypeptide relationships. J Bacteriol 161, 189-198.

Walkenhorst, H. M., Hemschemeier, S. K. \& Eichenlaub, R. (1995). Molecular analysis of the molybdate uptake operon, $\bmod A B C D$, of Eschericbia coli and $\operatorname{modR}$, a regulatory gene. Microbiol Res 150, 347-361.

Walmsley, J., Toukdarian, A. \& Kennedy, C. (1994). The role of regulatory genes nif $A, \operatorname{vnf} A$, anf $A, n f r X, n \operatorname{tr} C$ and $r p o N$ in expression of genes encoding the three nitrogenases of Azotobacter vinelandii. Arch Microbiol 162, 422-429.

Wang, G., Angermuller, S. \& Klipp, W. (1993). Characterization of Rhodobacter capsulatus genes encoding a molybdenum transport system and putative molybdenum-pterin-binding proteins. J Bacteriol 175, 3031-3042.

Wanner, B. L. (1993). Gene regulation by phosphate in enteric bacteria. $J$ Cell Biochem 51, 47-54.

Willsky, G. R. (1990). Vanadium in the biosphere. In Vanadium in Biological Systems: Physiology and Biology, pp. 1-24. Edited by N. D. Chasteen. Dordrecht: Kluwer Academic Publishers.

Yanisch-Perron, C., Vieira, J. \& Messing, J. (1985). Improved M13 phage cloning vectors and host strains: nucleotide sequences of the M13mp18 and pUC19 vectors. Gene 33, 103-119.

Received 19 January 1996; revised 1 April 1996; accepted 12 April 1996. 